\title{
619 惑星探査のための小型振動加工機の開発
}

\section{Development of Small Vibratory Crusher for Planetary Exploration}

\author{
○古谷克司（豊田工大） \\ 三枝嘉孝（豊田工大）
}

田形泰健（豊田工大）

Katsushi FURUTANI, Toyota Technological Institute, 12-1, Hisakata 2-chome, Tempaku-ku, Nagoya

Yasutake TAGATA, Toyota Technological Institute

Yoshitaka MIEDA, Toyota Technological Institute

This report deals with a small and light drilling machine by using a piezoelectric actuator. The piezoelectric actuator itself hits a drill stem by reciprocating between a stopper and the stem. The collision of the piezoelectric actuator with the stopper or the tool was detected by the reverse current from the actuator caused by the generated charge. The device could generate an impact force of $150 \mathrm{~N}$ with an average frequency of the impulse of $120 \mathrm{~Hz}$. The machine could crush pumice and gypsum. In addition a surface of basalt could be removed.

Key words: Piezoelectric actuator, Crusher, Vibration, Collision

\section{A 1.はじめに}

近年, 原始太陽系のイベントの発生時期や現象の調查のた め, 月や小惑星で少量の試料を採取して地球に持ち帰るサン プル・リターンが計画されている。試料採集で使用される振 動加工機は小型・軽量で消費電力が少ないものが望ましいた め，衝撃力を利用したものが有効であると考えられる．そこ で本研究ではさらに小型な振動加工機を開発するために, ア クチュエータ自体で打擊する機構を提案することを目的と する

\section{A 2. 試作した振動加工機と動作原理}

振動加工機の概略を図 A1 に示す．振動加工機は圧電素子 を超鋼の板で挟んだハンマ, ハンマを工具側に反発させるた

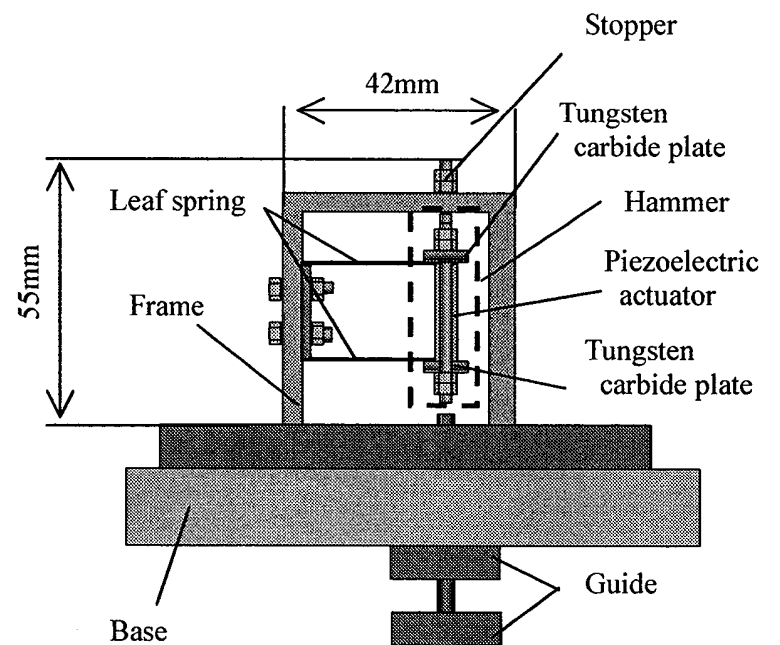

Drill stem

Anvil

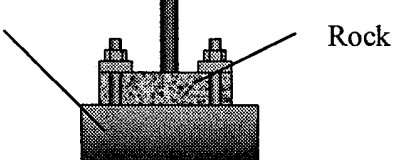

Fig. Al Schematic view of crusher
めのストッパ, ハンマの振動方向を拘束するための板ばね, 岩石をたたく工具, さらにこれらを固定するためのフレーム で構成される，ハンマは压電素子であり，それ自体が伸縮を 繰り返すことで, 工具とストッパの間を往復し, 衝撃力を発 生する。

\section{A 3. 振動加工機の性能}

図 A2 のようにほぼ一定間隔で衝撃力が発生した（打撃が 正). ハンマの移動速度および発生する衝撃力は，ハンマと 工具の間隔が $1.7 \mathrm{~mm} \sim 1.9 \mathrm{~mm}$ 付近で最大になった.

岩石は破砕を行う面が平らになるように整形した. 岩石と 衝突する部分の形状が図 $\mathrm{A} 3$ のような $\phi 3.9 \mathrm{~mm} \times 100 \mathrm{~mm}$ の超 鋼製の工具を使用し, 試料として石膏を 60 分間かけて破砕 した。結果を図 A4 に示す。脆い岩石の破砕や岩石の風化し た部分の除去に使用可能であると考えられる.

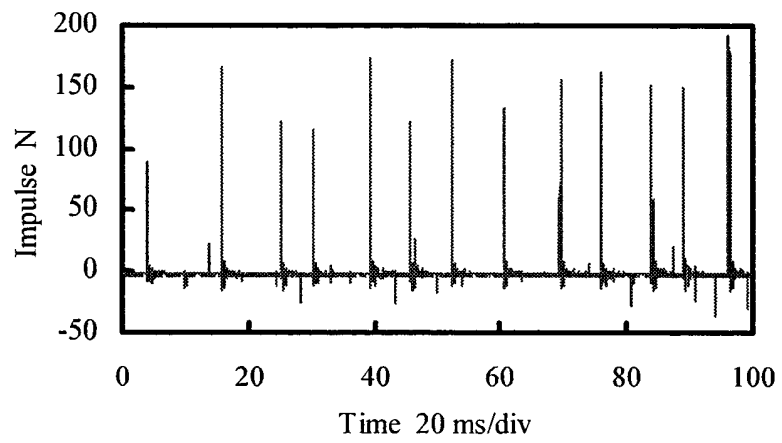

Fig. A2 Generative force of crusher

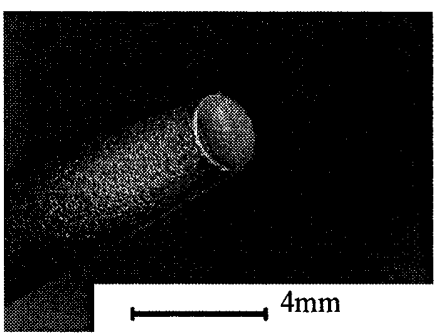

Fig. A3 Shape of tool tip (Tungsten carbide)

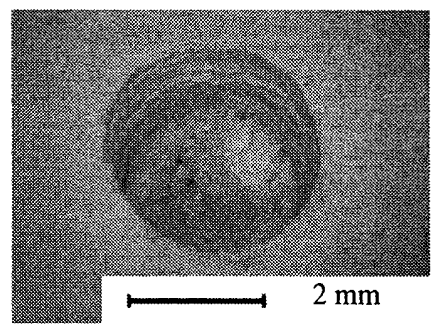

Fig. A4 Machined hole (gypsum) 


\section{1.はじめに}

近年, 原始太陽系のイベントの発生時期や現象の調査を月 や小惑星の物質の分析によって行おうとする動きがある。し かし，大きな分析装置を現地まで持っていくには，巨大な挆 査機が必要であり技術的，コスト的な困難を伴う。そこで月 や小惑星に行き少量の試料を採取して地球に持ち帰るサン プル・リターンが計画されている. 試料を採取する装置以外 も運ぶことを考えると採集装置は小型・軽量で消費電力が少 ないものが望ましい. 試料を採集することのみが求められて いるので岩石を破砕する際には精度が求められない. 様々な 方法が提案されているが(1)-(4)，試料採集には衝撃力や振動を 利用したものが有効であると考えられる.アメリカ・ジェッ 卜推進研究所 (NASA/JPL) は, 超音波振動子を利用して衝 撃力を発生する振動加工機(Ultrasonic/ Sonic Driller/ Corer: USDC)を開発している(1). しかし，振動振幅を増幅するため の超音波ホーンの寸法が振動子の共振周波数により制限さ れるため，小型化には限界があると考えられる。

そこで本研究ではさらに小型な振動加工機を開発するた めに,アクチュエータ自体で打撃する機構を提案することを 目的とする．以下では振動加工機の試作を行い，その性能を 評価した結果について述べる.

\section{2. 試作した振動加工機と動作原理}

振動加工機の構成と工具の加振原理を図 2 に示す.アクチ ユエータにより伸縮されるハンマがストッパと工具の間に 置かれている. 次のサイクルを繰り返しハンマで工具を打撃 することで, 工具と岩石の間に連続して衝撃力を加える. (1) ハンマがストッパと衝突する. (2)衝突した瞬間に圧電素子を 急速に伸ばす. (3)ハンマはストッパから離れ, 工具側に移動 する. (4)圧電素子を縮める. (5)ハンマが工具と衝突する. (6) (2)と同様. (7)八ンマが工具から離れ, ストッパ側に移動する. (8)(4)と同様. (1)に戻る.

本方法では，アクチュエータの共振を利用せず，アクチュ エータ自体をハンマとして利用するため, 装置の小型化, 軽

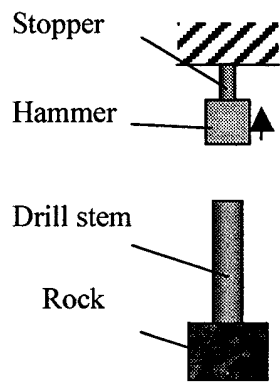

(1)
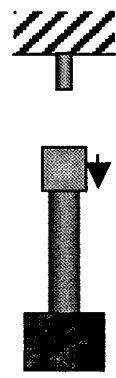

(5)
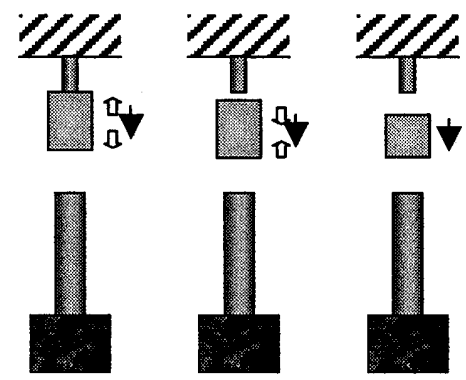

(3)

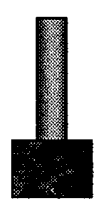

(4)
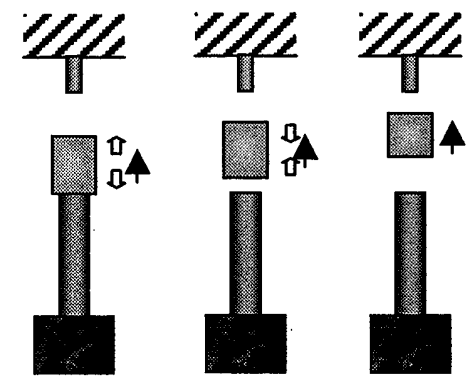

(6)

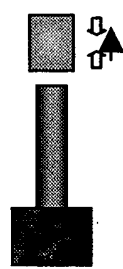

(7)

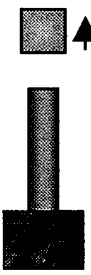

(8)

Fig. 1 Principle of vibration generation

量化が期待できる

振動加工機の構造を図 2 に示す. 振動加工機は圧電素子を 超鋼の板で挟んだハンマ, ハンマを工具側に振動させるため のストッパ，ハンマの振動方向を拘束するための板ばね，岩 石をたたく工具, さらにこれらを固定するためのフレームで 構成される. 振動加工機は台座上に載せられ，台座を上下さ せることにより送られる．また，工具が倒れるのを防ぐため ガイドを設けた. 工具を除いたサイズは $42 \mathrm{~mm} \times 55 \mathrm{~mm} \times 14 \mathrm{~mm}$, 質量は $67 \mathrm{~g}$ である. 圧電素子の寸法は $5 \mathrm{~mm} \times 5 \mathrm{~mm} \times 20 \mathrm{~mm}$ で $100 \mathrm{~V}$ 印加時に $11.6 \mu \mathrm{m}$ 伸びる. 2 本の M2 ボルトを側面で締 め付けて予圧をかけた。 圧電素子を伸縮させるために, パル ス幅 $167 \mu \mathrm{s}$, 波高值 $90 \mathrm{~V}$ の矩形波を印加した。 ハンマがスト ッパまたは工具と衝突すると，圧電素子から電流が逆向きに 流れる.これをカレントトランスで測定し, 衝突を検出した. このほかに, 電気的な接触を用いることで, 接触している時 間を測定した. 衝撃力の測定時には岩石の代わりに圧電式口 一ドワッシャを置いた. ハンマの変位はハンマとストッパが 接する位置を基準とし, ハンマが工具へ向かう方向を正とし て測定した.

\section{3. 振動加工機の性能}

\section{3・1 ハンマ伸長のタイミング}

ハンマと工具が衝突したときの例を図 3 に示す.上からハ ンマへの印加入力電圧, ハンマの変位, ハンマと工具との接 触検知, 衝撃力である. 接触検知後, 圧電素子を伸ばす時間 を $0.016 \mathrm{~ms}$ として衝撃力が発生させた. 入力を加えない場合 にハンマと工具が接触する時間は $0.192 \mathrm{~ms}$ であった. 圧電素 子を伸ばさない場合の衝撃力は $27 \mathrm{~N}$ であったが, 伸ばすこと で同図の場合には $91 \mathrm{~N}$ の衝撃力が発生した. ハンマを静止し た工具に衝突させ, 衝突してからハンマを伸ばすまでの時間 を変化させた場合の速度の変化と衝撃力とを表 1 に示す. 衝 突の前後では変位が直線的に変化しているため, その傾きを 速度とした．速度比は，ハンマが工具に衝突する速度に対す

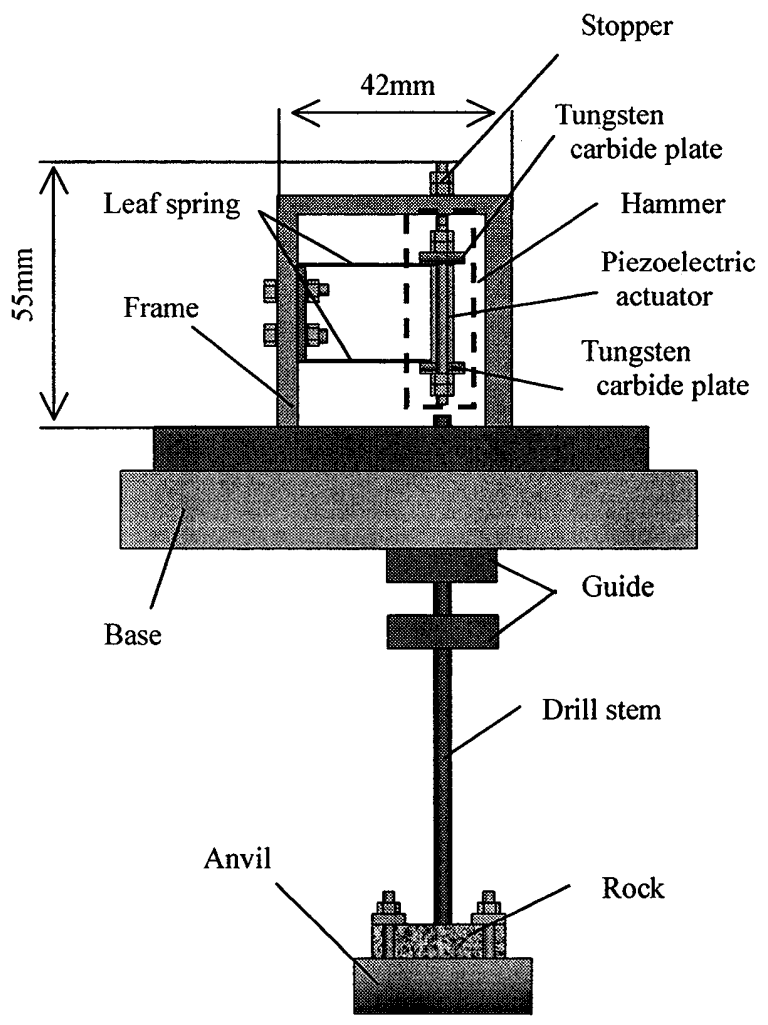

Fig. 2 Schematic view of crusher 


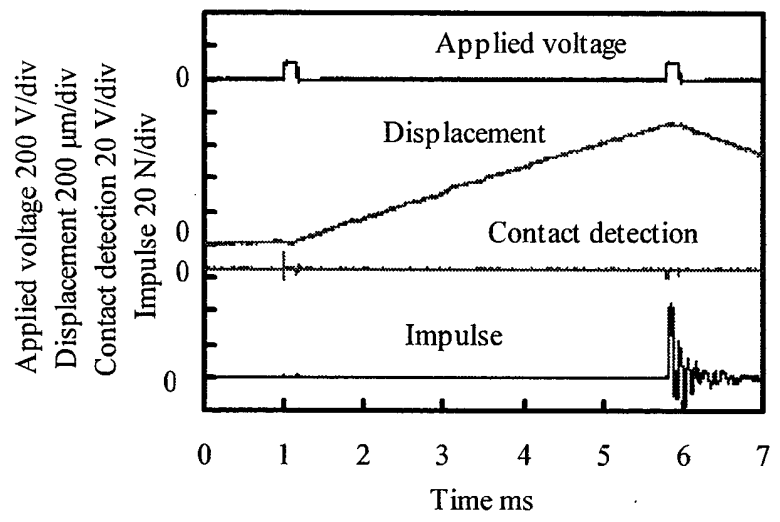

Fig. 3 Example of hammer displacement and impulse

Table 1 Influence of timing of extension

\begin{tabular}{|c|c|c|}
\hline $\begin{array}{l}\text { Lapse time after } \\
\text { collision } \mathrm{ms}\end{array}$ & Velocity ratio & $\begin{array}{l}\text { Maximum } \\
\text { impulse } \mathrm{N}\end{array}$ \\
\hline 0.016 & 1.10 & 87.4 \\
\hline 0.069 & 1.07 & 53.0 \\
\hline 0.102 & 1.13 & 46.3 \\
\hline 0.132 & 1.40 & 43.7 \\
\hline 0.184 & 1.15 & 33.9 \\
\hline
\end{tabular}

る衝突後の速度の比である. いずれの場合にも加速されたた め, 速度比は 1 を超えた。定常速度は飽和するが，圧電素子 の伸長の速度より大きい，したがって，振動した状態を維持 できる. 速度は衝突後の経過時間に対して一定の傾向が見ら れなかった．経過時間が短いほど衝撃力は大きかった．衝突 時の衝撃力と圧電素子が伸びることによる衝撃力がほぼ同 時に発生することで, 足しあわされた衝撃力となるためであ ると考えられる. 衝撃力が高いほど破砕の効率が良いので， 今回は衝突を検知してから最短でハンマを伸ばすタイミン グの(1)を使用した。

\section{2 振動加工機の基本特性}

ギャップ長を $0.7 〜 2.4 \mathrm{~mm}$ の間で設定し，基本特性を測定 した.

ギャップ長が 1.9mm の場合のハンマ変位と衝撃力の例を 図 4 に示す. 縦軸のハンマ変位は上が工具側で, 衝撃力は正 が打撃を示す，衝撃力の発生間隔はほぼ一定であった。 ハン マは初期に設定したハンマと工具の間隔（以下ギャップ長） よりも狭い範囲を移動した。これは，工具がハンマに吒かれ てロードセルから弾んでいることが原因であると考えられ る.

ハンマと工具の間隔とハンマの移動速度および発生する 衝撃力の平均値との関係を図 5 に示す. 速度, 衝撃力共に $1.7 \mathrm{~mm} \sim 1.9 \mathrm{~mm}$ 付近で最大になった. 衝撃力は運動量に依存 し, ハンマと工具の質量はそれぞれ一定である。したがって， 衝撃力と速度の傾向は同様になったと考えられる。

ギャップ長と単位時間当たりの衝撃回数の関係を図6に示 す. 図中の衝撃回数の限界は入力信号によって決定される值 である、衝撃回数はギャップ長が広くなるに従い減少した。 これはハンマの移動距離が増加し，ストッパと工具の間を往 復するために必要な時間が増加したことが原因である.

破砕は衝撃力が高いほど効率が良いため，ギャップ長を

$1.7 \mathrm{~mm} \sim 1.9 \mathrm{~mm}$ として岩石の破砕を行った。

\section{3 岩石の破砕実験}

破砕した試料には，軽石，石膏，玄武岩を使用した，破砕 する面が平らになるようにあらかじめ整形してから加工し た，使用した超硬工具の寸法は，直径 $3.9 \mathrm{~mm}$, 長さ $100 \mathrm{~mm}$

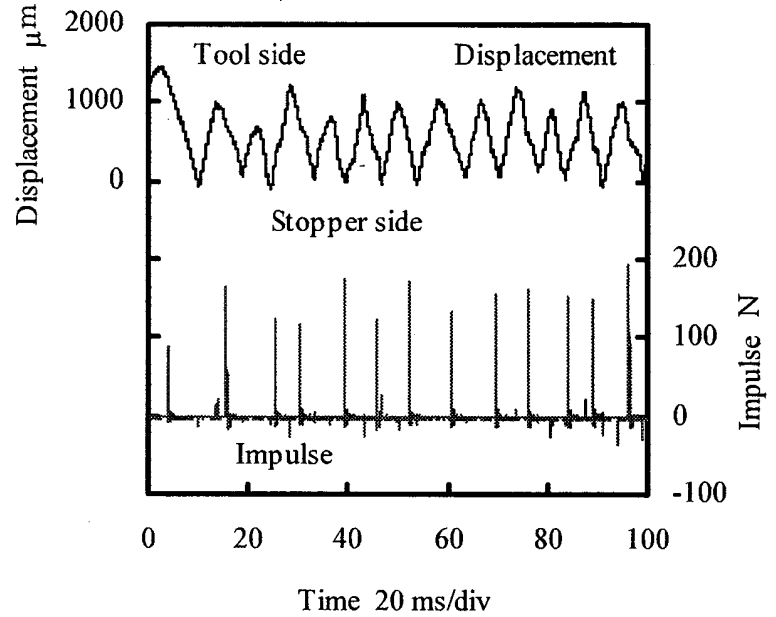

Fig. 4 Generative force of crusher

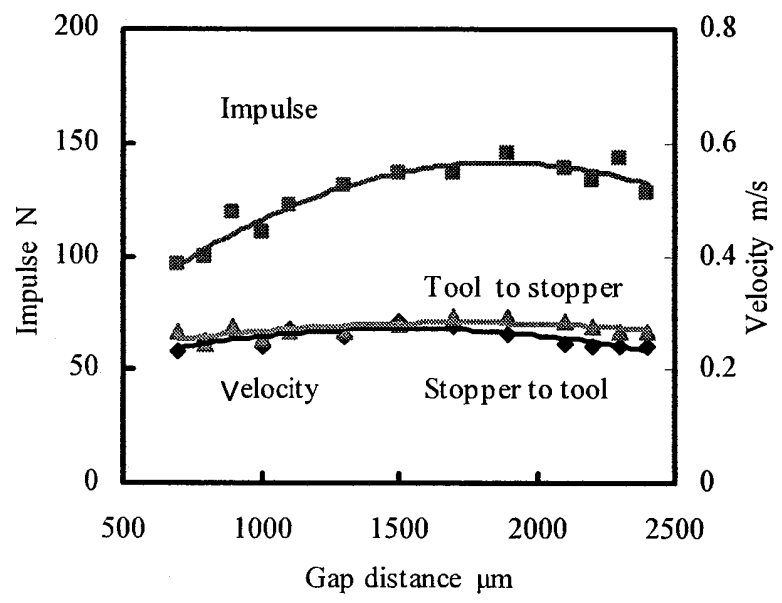

Fig. 5 Average of impulse and hammer velocity

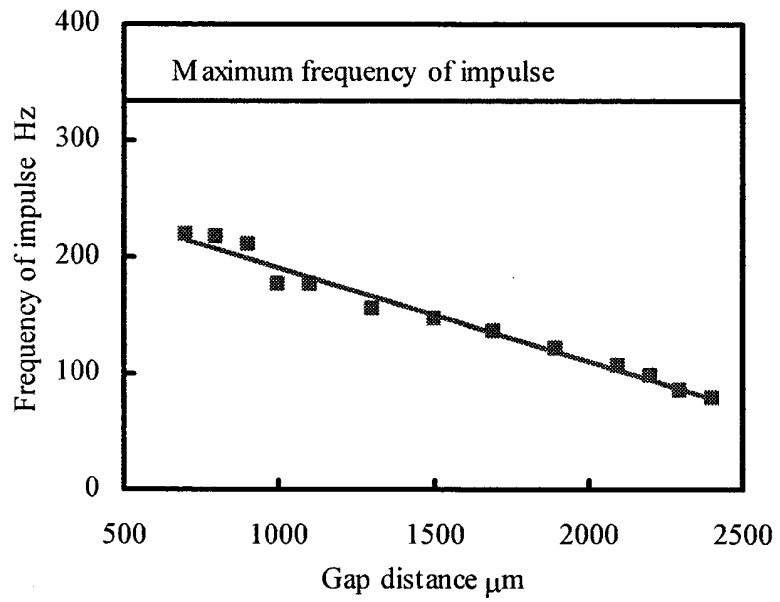

Fig. 6 Relationship between frequency of impulse and gap distance

である. 先端の形状は図 7 に示す 3 種類を用いた。

加工後の試料の外観を図 8 に示す. 軽石を 5 分間破砕した 結果, 穴径は $\phi 4.3 \mathrm{~mm}$, 深さは $4 \mathrm{~mm}$ であった。また, 質量 が $6 \mathrm{mg}$ 減少した。試料として石高を 60 分間かけて破砕した 


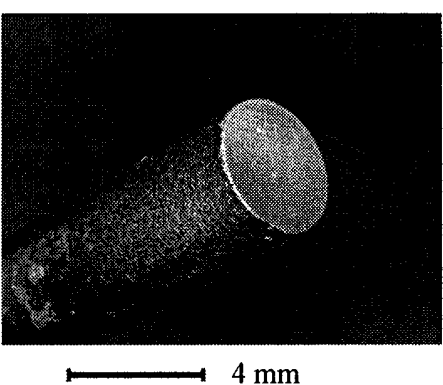

(a) Flat

(For pumice)

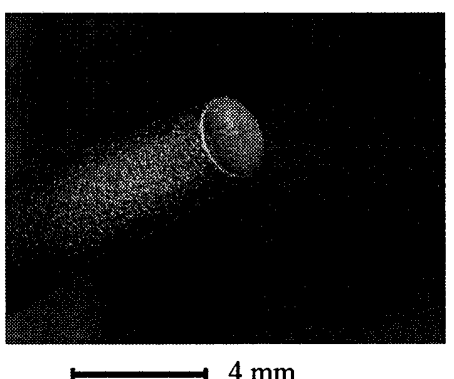

(b)Frustum

(For gypsum)

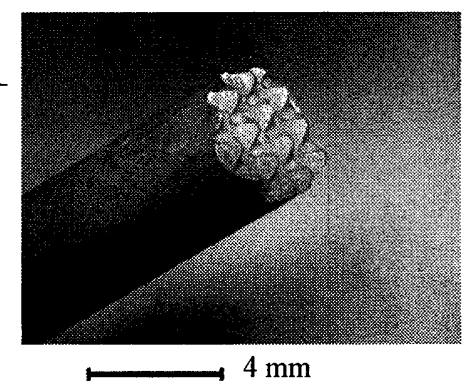

(b) Multiple pyramids (For basalt)

Fig. 7 Tip shapes of drill stems made of tungsten carbide

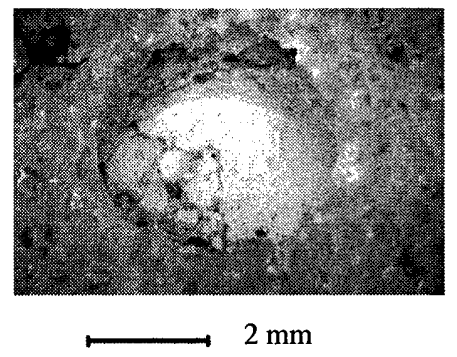

(a) pumice

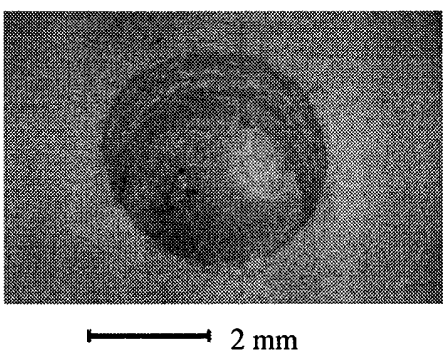

(b) Gypsum

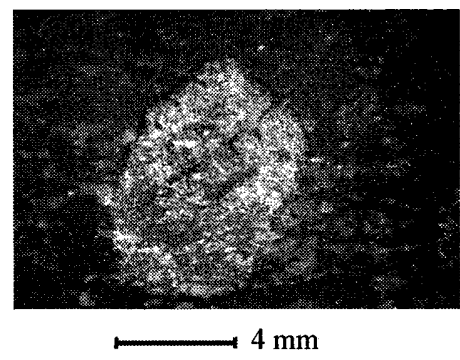

(c) Basalt

Fig. 8 Results of machining

Table 2 Comparison of developed crusher with USDC

\begin{tabular}{|c|c|c|c|c|c|c|c|c|}
\hline & Impulse & $\mathrm{N}$ & Impulse frequency & $\mathrm{Hz}$ & Dimensions $\mathrm{mm}$ & Mass & Average power & $\mathrm{W}$ \\
\hline Developed crusher & 150 & & 120 & & $42 \times 55 \times 14$ & 67 & 4 & \\
\hline $\mathrm{USDC}^{(1)}$ & 350 & & 1100 & & $\phi 36 \times 111$ & 450 & 12 & \\
\hline Crusher/ USDC & 0.43 & & 0.11 & & 0.38 in length & 0.15 & 0.33 & \\
\hline
\end{tabular}

場合には, 工具の先端は $\phi 2.2 \mathrm{~mm}$ のときに加工した穴の底面 の直径は $2.9 \mathrm{~mm}$ であった.最も深く掘れた位置の深さは $2 \mathrm{~mm}$ であった．また，加工により除去されていた質量は $20 \mathrm{mg} て ゙$ あった．また玄武岩の表層を除去することもできた。したが って脆い岩石の破砕や岩石の風化した部分の除去に使用可 能であると考えられる.

\section{USDC との比較}

超音波振動子を利用した振動加工機である USDC と比較 を行った結果を表 2 に示す. 試作した振動加工機の值は, ギ ヤップ長が $1.9 \mathrm{~mm}$ の場合の值である.USDC は超音波振動子, ホーン, フリーマス, 工具で構成される. ホーンを超音波振 動させることによってフリーマスを吅き, さらにこれが工具 に衝突し, 岩石の閒に衝撃力を与える ${ }^{(1)}$. USDC の值は論文 に記載されたものである. USDC に対して破砕の性能は劣 るが, 小型化・低電力化は達成された. 今後はさらに衝撃力 を向上させる必要がある.

$$
\text { 5. まとめ }
$$

本研究ではアクチュエータ自体を打撃するために振動さ せることにより小型化した振動加工機を開発した. 結果をま とめると以下のようになる.

(1) 試作した振動加工機でギャップ長と衝撃力, 衝撃回数の 関係を明らかにした。

（2）試作した振動加工機で軽石と石高を破砕できた。また，
玄武岩の表層を除去できた。

研究の遂行に当たりご助言いただいた JAXA/ISAS 久保田 孝助教授, 中央大学國井康睛助教授, 豊田工業大学近藤一義 客員教授に感謝いたします. 本研究の一部には文部科学省私 立大学ハイテク・リサーチ・センタ一整備事業補助金(平成 15 年度〜平成 19 年度)「宇宙ロボティクス研究センター」を 用いました。記して感謝いたします。

\section{文献}

(1) X. Bao, Y. Bar-Cohen, Z. Chang, B. P. Dolgin, S. Sherrit, D. S $\mathrm{Pal}, \mathrm{S}$. Du, T. Peterson: Modeling and Computer Simulation of Ultrasonic/ Sonic Driller/ Corer (USDC), IEEE Trans. Ultrasonics, Sonics and Frequency Control, 50, 9 (2003) 1147-1160.

（2）多田興平, 國井康晴, 久保田孝, 大竹真紀子 : 超音波を 用いた検索システムにおけるホーン形状の研削性能評価, 第 47 回宇宙科学技術連合講演会講演集, (2003) 1489-1490.

(3) A. Sukhanov, O. Durao: Autonomous Navigation And Sample Collection for the Low-cost Main-belt Asteroid Sample Return Mission, J. Spacer Rockets, 38, 5, (2001) 736-744.

(4) B. Dachwald, W. Seboldt, L. Richter: Multiple Rendevous and Sample Return Mission to Near-Earth Objects Using Solar Sailcraft, 5th IAA Conf. Low-Cost Planetary Missions (2003) $5-6$. 